\title{
ANALISIS REKRUTMEN DAN PENEMPATAN KERJA TERHADAP KINERJA KARYAWAN PADA HOTEL OASE
}

\author{
MUHAMMAD ARIF \\ Universitas Islam Riau \\ Jl. Kaharuddin Nasution, No. 113, Perhentian Marpoyan Pekanbaru 28284 \\ e-mail: muhammadarif@fis.uir.ac.id
}

\begin{abstract}
Abstrak: Penelitian ini dilakukan di Hotel Oase Pekanbaru yang beralamat lengkap di jalan Jenderal Sudirman No. 255 EF (Simpang Jl. K.H. Wahid Hasyim) Pekanbaru. Adapun tujuan dari penelitian ini adalah untuk mengetahui pengaruh rekrutmen dan penempatan terhadap kinerja karyawan pada Hotel Oase Pekanbaru. Adapun jenis dan sumber data yang digunakan dalam penelitian ini adalah terdiri dari data primer dan data sekunder dengan jumlah sampel sebanyak 30 orang. Pengambilan sampel dilakukan dengan menggunakan metode sensus. Sedangkan untuk mengetahui besarnya pengaruh variabel bebas $(\mathrm{X})$ terhadap variabel terikat $(\mathrm{Y})$ digunakan analisa Regresi Linear Berganda dengan bantuan perangkat SPSS versi 17.0. Berdasarkan hasil Uji Regresi Linear Berganda di peroleh persamaan: $\mathrm{Y}=19.180+0.051 \mathrm{X}_{1}+0.161 \mathrm{X}_{2}$. Kemudian dari hasil Uji secara Simultan (Uji F) diketahui bahwa variabel rekrutmen dan penempatan secara bersama-sama berpengaruh signifikan terhadap kinerja karyawan pada Hotel Oase Pekanbaru. Sedangkan berdasarkan hasil Uji secara Parsial (Uji t) diketahui bahwa variabel rekrutmen dan penempatan secara parsial memberikan pengaruh yang signifikan terhadap kinerja karyawan pada Hotel Oase Pekanbaru. Sedangkan berdasarkan perhitungan nilai Koefisien Determinasi $\left(\mathrm{R}^{2}\right)$ diperoleh nilai Adjusted R Square sebesar 0.703. Hal ini menunjukkan bahwa variabel rekrutmen dan penempatan kerja secara keseluruhan memberikan pengaruh sebesar $70.3 \%$ terhadap kinerja karyawan pada Hotel Oase Pekanbaru. Sedangkan sisanya sebesar 29,7 \% adalah dipengaruhi oleh variabel lain yang tidak diteliti dalam penelitian ini.
\end{abstract}

Kata Kunci: Kinerja, Rekrutmen, Penempatan

\section{PENDAHULUAN}

Pada abad ke 21 ini yang merupakan era kompetisi global, setiap perusahaan menghadapi tingkat persaingan yang semakin tajam. Untuk menghadapi persaingan tersebut, perusahaan seharusnya memiliki keunggulan kompetitif (competitive advantage) tertentu dibandingkan dengan para pesaingnya. Perusahaan yang memiliki keunggulan kompetitif umumnya memiliki sumber-sumber yang dapat diandalkan dalam rangka memenangkan persaingan. Salah satu sumber tersebut adalah sumber daya manusia.

Keunggulan daya saing yang lain seperti teknologi produk, desain organisasi memerlukan bantuan sumber daya manusia untuk mengoperasikannya. Kompetisi yang dimiliki sumber daya manusia membuat sumber daya manusia itu sendiri mampu menggali potensi dan mengoptimalkan pemanfaatan sumber daya yang lainnya untuk mencapai profitabilitas perusahaan. Untuk dapat mencapai profitabilitas tersebut, sumber daya manusia harus diperhatikan dengan 
baik karena manusia adalah sumber daya terpenting suatu perusahaan yang memberikan tenaga, bakat, kreatifitas dan usahanya kepada perusahaan.

Mengingat peranan sumber daya manusia yang sedemikian berharga bagi perusahaan, manejer harus mampu mempersiapkan, mengelola dan mempertahankan sumber daya manusia yang dimilikinya agar sumber daya manusia tersebut mampu memberikan kontribusi secara optimal terhadap pencapaian organisasi.

Salah satu permasalahan yang sering dihadapi oleh seorang manajer ialah pengelolaan manajemen sumber daya manusia, hal ini dikarenakan manajemen sumber daya manusia itu memiliki tingkat persaingan yang tinggi untuk meningkatkan kualitas sumber daya manusia dan membutuhkan manajemen perusahaan yang baik agar tujuan yang telah disepakati bersama dapat tercapai.

Pada saat ini, kepariwisataan sangat besar peranannya dalam menambah pemasukan devisa negara dan juga memperluas kesempatan kerja serta pemerataan pendapatan. Hampir setiap tahunnya arus wisatawan menunjukkan peningkatan dan mempunyai peluang yang cerah pada masa yang akan datang. Agar usaha peningkatan arus wisatawan ini dapat memberikan pemasukan pada kas daerah maka perlu kiranya diimbangi oleh penyediaan sarana dan prasarana yang mendukung ke arah sektor tersebut. Dengan tersedianya sarana tersebut dapat menciptakan suasana yang menyenangkan dan nyaman bagi wisatawan baik dari dalam maupun luar negeri.

Usaha penyediaan sarana dan prasarana ini didukung oleh peranan pemerintah daerah yakni dengan cara perbaikan jalan, transportasi, pengenalan objek wisata lokal kepada daerah lain ataupun negara lain agar potensi wisata dapat lebih dikenal. Usaha tersebut diharapkan dapat memancing wisatawan yang datang serta meningkatkan jumlahnya dari tahun ketahun. Dengan peningkatan jumlah wisatawan, tentunya hal ini mendorong pihak manajemen perhotelan untuk mengembangkan usahanya agar dapat menampung jumlah wisatawan yang datang.

Peningkatan ini tentunya akan memberikan dampak yang berbeda yang mana akan menambah jumlah pesaing dan merupakan ancaman bagi usahanya, karena persaingan akan semakin ketat. Dalam usaha menarik pelanggan, pihak pengusaha sebaiknya lebih berhati-hati dalam melaksanakan kebijaksanaan yang akan ditempuh agar tidak menimbulkan hal-hal yang tidak diinginkan baik masa sekarang maupun pada masa yang akan datang.

Masalah tenaga kerja pada akhirakhir ini merupakan masalah yang kompleks karena adanya perkem-bangan teknologi yang semakin pesat dan adanya pertumbuhan persaingan. Tantangan utamanya adalah bagaimana memilih, mengelola karyawan dengan efektif dan menghapuskan praktek-praktek yang tidak selektif, yaitu dengan cara ketepatan melakukan kegiatan rekrutmen. Hal ini kan terlihat dari hasil penilaian kinerja setelah para pekerja melaksanakan tugas-tugas pokoknya untuk satu periode tertentu. Dalam kondisi lingkungan di atas, seorang manejer dituntut untuk selalu mampu mengembangkan cara-cara baru untuk dapat menyeleksi dan mempertahankan karyawan yang berkualitas tinggi agar perusahaan tetap mampu bersaing.

Salah satu hotel yang ada di Pekanbaru adalah hotel Oase, yang merupakan hotel berkelas melati. Berbagai usaha dilakukan oleh manajemen hotel Oase untuk meningkatkan tingkat hunian kamar hotelnya dengan berbagai kebijakan yang diterapkan. 
Untuk dapat bertahan dan bersaing dengan usaha yang sejenis, pihak manajemen hotel Oase melakukan berbagai cara agar jumlah pelanggan semakin meningkat. Baik itu fasilitas, kenyamanan, dan yang terpenting adalah pelayanan yang optimal. Untuk mencapai tujuan tersebut pihak manajemen hotel Oase sangat memperhatikan kualitas karyawan (SDM) yang ada, dari tahun ke tahun hotel Oase mengalami peningkatan jumlah karyawan. Adapun rinciannya dapat dilihat pada tabel berikut :

Tabel 1

Jumlah Karyawan Hotel Oase Tahun 2006-2011

\begin{tabular}{ccccc}
\hline \multirow{2}{*}{ No } & \multirow{2}{*}{ Tahun } & \multicolumn{2}{c}{ Jumlah Karyawan } & \multirow{2}{*}{ Total } \\
\cline { 3 - 4 } & & Lk & Pr & \\
\hline 1 & 2006 & 20 & 5 & 25 orang \\
\hline 2 & 2007 & 19 & 4 & 23 orang \\
\hline 3 & 2008 & 25 & 6 & 31 orang \\
\hline 4 & 2009 & 24 & 7 & 31 orang \\
\hline 5 & 2010 & 25 & 5 & 30 orang \\
\hline 6 & 2011 & 25 & 5 & 30 orang \\
\hline
\end{tabular}

Dari tabel 1, dapat dilihat bahwa jumlah karyawan hotel Oase Pekanbaru dari tahun ke tahun mengalami penurunan dan peningkatan. Dimana pada tahun 2006 jumlah karyawan sebanyak 25 orang yang terdiri dari 20 orang karyawan laki-laki dan 5 orang karyawan perempuan. Pada tahun 2007 jumlah karyawan sebanyak 23 orang yang terdiri dari 19 orang karyawan laki-laki dan 4 orang perempuan. Pada tahun 2008 jumlah karyawan sebanyak 31 orang yang terdiri dari 25 orang laki-laki dan 6 orang perempuan. Pada tahun 2009 jumlah karyawan sebanyak 31 orang yang terdiri dari 24 orang laki-laki dan 7 orang perempuan. Pada tahun 2010 jumlah karyawan sebanyak 30 orang yang terdiri dari 25 orang laki-laki dan 5 orang perempuan. Pada tahun 2011 jumlah karyawan sama dengan jumlah karyawan pada tahun 2010.

Dengan adanya peningkatan jumlah karyawan disetiap tahunnya, tentunya harus dibarengi dengan latar belakang pendidikan masing-masing, agar upaya pencapaian tujuan dapat dicapai.
Setelah melalakukan tinjauan sementara, ditemukan bahwa penerapan hasil analisis jabatan pada hotel Oase Pekanbaru belum sesuai dengan analisa jabatan yang telah dilakukan dimana terdapat kekurangan karyawan pada setiap bagian, yang mana jumlah karyawan pada bagian tersebut tidak sesuai dengan kebutuhan sumber daya manusia pada hotel Oase. Misalnya pada departemen Front Office dibutuhkan karyawan sebanyak 6 orang, tetapi yang ada saat ini hanya 5 orang karyawan, dengan demikian ada 1 kekosongan jabatan pada bagian Front Office. Begitu juga dengan jabatan-jabatan yang lain yang rata-rata masih terdapat kekosongan jabatan.

Begitu juga dari segi kualitas, terlihat bahwa klasifikasi jabatan berdasarkan latar belakang pendidikan banyak yang tidak sesuai dengan syarat yang semestinya, contohnya masih ada karyawan yang berlatar belakang pendidikan yang tidak dari perhotelan.

Dengan keadaan yang ada, tentunya pihak manajemen hotel Oase Pekanbaru harus memikirkan bagaimana 
tetap unggul dengan pesaingnya yang semakin hari semakin bertambah. Tentunya dengan keadaan tersebut bisa diwujudkan dengan kualitas sumber daya manusia yang harus benar-benar berkualitas serta memahami tugas pokok dan fungsi masing-masing dimana ia ditempatkan.

Berikut adalah persentase tingkat hunian kamar hotel Oase Pekanbaru lima tahun terakhir:

Tabel 2

Persentase tingkat hunian kamar hotel Oase Pekanbaru tahun 2007-2011

\begin{tabular}{cccc}
\hline No & Tahun & Jumlah Kamar & Persentase Hunian \\
\hline 1 & 2007 & 23 & $60 \%$ \\
\hline 2 & 2008 & 27 & $55 \%$ \\
\hline 3 & 2009 & 27 & $70 \%$ \\
\hline 4 & 2010 & 35 & $60 \%$ \\
\hline 5 & 2011 & 38 & $80 \%$ \\
\hline
\end{tabular}

Dari tabel di atas dapat dilihat persentase tingkat hunian kamar hotel Oase Pekanbaru berfluktuasi, tahun 2007 kamar yang tersedia 23 kamar dan terjual mencapai 60 persen, tahun 2008 kamar yang tersedia 27 kamar dan terjual selama tahun 2008 sebesar 55 persen, tahun 2009 kamar yang tersedia 27 kamar dan terjual selama setahun 70 persen, pada tahun 2010 mengalami penurunan dari kamar yang tersedia 35 kamar dan terjual sebesar 60 persen, dan pada tahun 2011 kamar yang tersedia 38 kamar dan terjual selama setahun sebesar 80 persen.

Melihat persentase penjualan kamar hotel Oase Pekanbaru, dapat dikatakan penjualan berfluktuasi dan cenderung tidak tercapainya target penjualan kamar yang harus mencapai 100 persen. Penjualan yang berfluktuasi dapat diasumsikan bahwa kurangnya produktivitas kerja karyawan, sehingga persentase penjualan cenderung berfluktuasi.

Melihat keadaan di atas penulis tertarik untuk mengadakan penelitian dengan judul "PENGARUH REKRUTMEN DAN PENEMPATAN TERHADAP KINERJA KARYAWAN PADA HOTEL OASE PEKANBARU".

Adapun yang menjadi perumusan masalah yang diajukan pada penelitian ini adalah: (1) Apakah Rekrutmen
Berpengaruh Terhadap Kinerja Karyawan Hotel Oase Pekanbaru ? (2) Apakah Penempatan Berpengaruh Terhadap Kinerja Karyawan pada Hotel Oase Pekanbaru ? dan (3) Apakah rekrutmen dan penempatan secara simultan berpengaruh terhadap kinerja karyawan pada Hotel Oase Pekanbaru? Sedangkan yang menjadi tujuan penelitian ini adalah: (1) untuk menganalisa rekrutmen dan penempatan karyawan hotel Oase Pekanbaru; (2) untuk menganalisa kinerja karyawan hotel Oase Pekanbaru; (3) Untuk mengetahui seberapa besar pengaruh rekrutmen terhadap kinerja karyawan hotel Oase Pekanbaru; (4) Untuk mengetahui seberapa besar pengaruh penempatan terhadap kinerja karyawan hotel Oase Pekanbaru. Adapun kegunaan penelitian ini adalah sebagai berikut: (1) Sebagai masukan kepada hotel Oase Pekanbaru dalam meningkatkan kualitas kerja karyawan secara efektif; (2) Sebagai salah satu wadah untuk meningkatkan pengetahuan penulis terutama tentangprogram rekrutmen dan penempatan terhadap karyawan; dan (3) Bagi pihak hotel Oase Pekanbaru dapat dijadikan bahan pedoman dalam melaksanakan proses rekrutmen dan penempatan yang efektif dalam meningkatkan produktivitas kerja karyawan. 


\section{KONSEP TEORI \\ Pengertian Rekrutmen}

Rekrutmen merupakan proses menentukan dan menarik pelamar yang mampu untuk bekerja dalam suatu perusahaan, proses ini dimulai ketika para pelamar dicari dan berakhir ketika lamaran - lamaran mereka diserahkan atau dikumpulkan, hasilnya adalah merupakan sekumpulan pelamar calon karyawan untuk diseleksi dan dipilih (Rivai, 2004 : 158).

Teori rekrutmen menurut Simamora (2001: 221), yakni: (1) Rekrutmen sering diberlakukan seolah-olah sebagai suatu proses satu arah (one-way process) yaitu sesuatu yang dilakukan perusahaan untuk mencari karyawan, pendekatan ini disebut teori rekrutmen "pencarian" (prospecting theori of rekruitment); dan (2) Calon karyawan dan manager mencari organisasi bagaimana halnya organisasi mencari mereka, pandangan ini disebut dengan teori rekrutmen "pasangan" (mating theory of recruitment).

Keberhasilan rekrutmen dan keberhasilan pencarian pekerjaan (dari persfektif calon karyawan) keduanya secara kritis tergantung pada waktunya. Manakala terdapat kecocokan antara upaya rekrutmen organisasional dengan upaya pencarian kerja pelamar, maka kondisinya dalam keadaan matang untuk bertemu. Tujuan utama yang ingin dicapai dari rekrutmen adalah menyediakan bagi organisasi sekelompok pelamar yang qualified. Tujuan sacara spesifik adalah : (1) Mengevaluasi keefektifan teknis dan lokasi rekrutmen untuk semua jenis pelamar pekerjaan; (2) Meningkatkan keefektifan individu dan organisasi dalam jangka panjang dan jangka pendek; (3) Menurunkan kemungkinan keluarnya pelamar setelah bekerja selama jangka waktu yang relatif singkat; (4) Membantu meningkatkan tingkat keberhasilan proses seleksi dengan mengurangi jumlah mereka yang sudah jelas under dan overqualifikas; (5) Meningkatkan jumlah pelamar yang qualified dengan biaya yang serendah mungkin; (6) Menentukan kebutuhan rekrutmen sekarang dan masa yang akan datang dalam hubungannya dengan perencanaan sumber daya manusia dengan analisis pekerjaan.

\section{ProsesRekrutmen Karyawan}

Proses rekrutmen yang baik harus menghasilkan karyawan yang merupakan pelaksana yang baik dan akan tetap bersama perusahaan sampai jangka waktu yang wajar (Simamora, 2004 : 173)

Menurut Umar (2001 : 8-9), untuk menjamin bahwa tenaga kerja yang diterima adalah yang paling tepat, baik dengan kriteria yang telah ditetapkan ataupun jumlah yang dibutuhkan perlu dilakukan usaha-usaha yang sistematis. Usaha-usaha sistematis tersebut adalah sebagai berikut: (1) Seleksi Dokumen; (2) Psikotes; (3) Tes Intelegensi; (4) Tes Kepribadian; (5) Tes Bakat dan Kemampuan; (6) Tes Kesehatan; dan (7) Wawancara.

\section{Rekrutmen dalam Islam}

Rekrutmen karyawan ini merupakan suatu hal yang penting dan kompleks karena untuk mendapatkan orang-orang yang kompeten serasi serta efektif tidaklah mudah. Proses perekrutan akan berakibat fatal bagi kelangsungan organisasi perusahaan tersebut. Oleh karenanya kita seyogyanya mengingat selalu Nabi Muhammad SAW dalam sabdanya: "Jika suatu urusan diserahkan kepada yang bukan ahli (tidak memiliki kompetensi, keahlian, keserasian, dan efektifitas) maka tunggulah kehancurannya"

Syari'at Islam sebagai sistem hidup bagi manusia yang sempurna (syumuliyatul Islam) mengatur berbagai aspek kehidupan, termasuk menyangkut sumber daya manusianya. Profesionalisme dalam konsep Islam tentunya menyangkut kualitas akal (al-fikr), kualitas hati nurani 
(ruhiyah) dan komitmen melaksanakan tugas (amaliyah). Ketiga unsur pokok tersebut sangat menentukan keberhasilan seseorang dalam mengelola kehidupannya. Karena Allah SWT telah memberikan modal yang sama kepada hambanya tidak dibedakan satu dengan lainnya. Allah SWT berfirman:

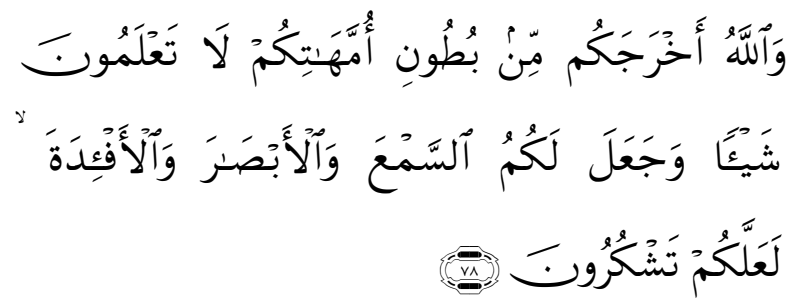

Artinya: "Dan Allah mengeluarkan kamu dari perut ibumu dalam keadaan tidak mengetahui sesuatupun, dan Dia memberi kamu pendengaran, penglihatan dan hati, agar kamu bersyukur" (QS. An Nahl, $16: 78)$.

Kenikmatan modal dasar yang diberikan Allah SWT selanjutkan tergantung bagaimana setiap manusia memanfaatkannya, jika ada kesungguhnya sudah dapat dipastikan akan berhasil dan memilih santai (ghoflah) hasilnya pun tidak memuaskan. Untuk menyiapkan karyawan yang mampu menjalankan tugas secara berdaya guna dan hasil guna dalam menjalankan fungsi sebagai aset perusahaan diawali pola rekrukmen pegawainya. Agama Islam memberikan rambu-rambu dalam rekrutmen pegawai yang dapat dijadikan kebijakan oleh para pengelola kepegawaian. Allah SWT berfirman:
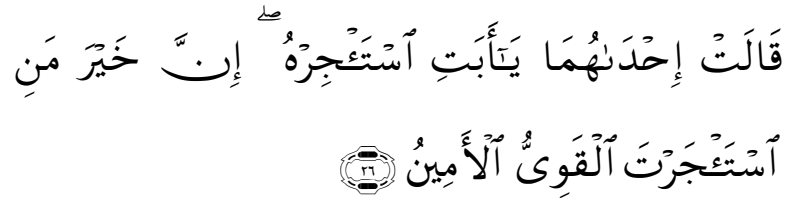

Artinya: "Salah seorang dari kedua wanita itu berkata: "Ya bapakku ambillah ia sebagai orang yang bekerja (pada kita), karena
Sesungguhnya orang yang paling baik yang kamu ambil untuk bekerja (pada kita) ialah orang yang kuat lagi dapat dipercaya" (QS. Al Qashash, 26 : 26).

Apabila dicermati dari ayat tersebut dalam rekrutmen pegawai dibutuhkan setidak-tidaknya dua syarat yaitu: " kuat dan amanah". Pertama, memiliki kekuatan meliputi kuat aqidah (quatul aqidah), cerdas (quatul fikr), wawasan jauh kedepan (tsaqofah), cerdas hati nuraninya (quatul ruhiyah) dan bekerja professional (itqon). Seorang pegawai yang memiliki kekuatan aqidah sudah dapat dipastikan akan tertanam dalam dirinya merasa dipantau (muroqobah) oleh Sang Pencipta. Dengan tertanamnya rasa dipantau dalam bekerja, maka akan melahirkan pribadi rajin dan ulet bekerja baik ada atasanya maupun dalam kesendirian, karena menjalankan tugas sebagai kewajib pribadi. Kekuatan aqidah juga perlu diimbangi kecerdasan berfikir sehingga bekerja akan berdasarkan nalar yang hidup. Kedua, seorang pegawai memiliki amanahnya dalam melaksanakan tugas dan fungsi yang diberikan kepadanya. Karena faktor amanah sangat dibutuhkan sebagai kontribusi nyata mewujudkan pemerintahan yang bersih (good governance). Kepercayaan masyarakat tidak terlepas sejauhmana para pegawai/karyawan mampu menjalankan tugas yang diembankannya melalui kerja jujur, disiplin dan bertanggung jawab. Mengingkari amanah yang diberikan kepada pegawai sesungguhnya telah melecehkan atau mengkhianati Allah SWT dan RasulNya. Allah SWT berfirman:
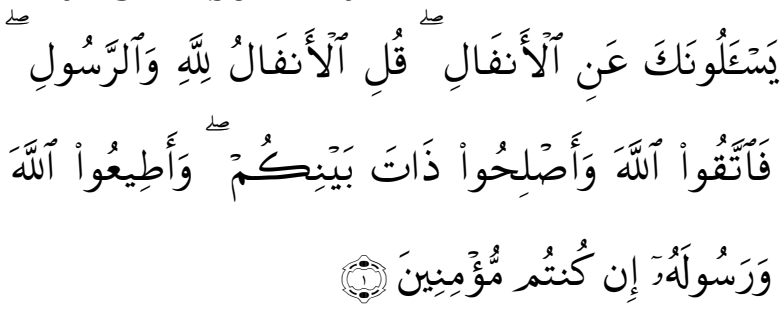
Artinya: "Hai orang-orang yang beriman, janganlah kamu mengkhianati Allah dan Rasul (Muhammad) dan (juga) janganlah kamu mengkhianati amanat-amanat yang dipercayakan kepadamu, sedang kamu mengetahui" (QS. Al Anfaal, 8: 2).

\section{Penempatan Kerja}

Penempatan adalah proses penugasan/pengisian jabatan atau pengisian jabatan atau penugasan kembali pegawai pada tugas/jabatan baru atau jabatan yang berbeda. Penugasan ini dapat berupa penugasan pertama untuk pegawai yang baru direkrut, tetapi dapat juga melalui promosi, pengalihan, dan penurunan jabatan bahkan pemutusan hubungan kerja (Hariandja, 2002 : 156).

Seperti halnya dengan pelaksanaan kegiatan-kegiatan lain dalam penempatan karyawan juga perlu dipertimbangkan beberapa faktor. Menurut Sastrohadiwiryo (2002), faktor yang perlu dipertimbangkan dalam penempatan tersebut adalah sebagai berikut: (a) Faktor Prestasi Akademis, faktor prestasi akademik yang telah dicapai oleh karyawan selama mengikuti jenjang pendidikan harus mendapatkan pertimbangan dalam menempatkan dimana karyawan yang bersangkutan harus melaksanakan tugas dan pekerjaannya serta wewenang dan tanggung jawab; (b) Faktor Pengalaman, Pengalaman para karyawan yang sejenis yang telah dialami sebelumnya, perlu mendapat pertimbangan dalam rangka penempatan karyawan. Pengalaman bekerja banyak memberikan kecenderungan bahwa karyawan memiliki keahlian dan keterampilan kerja yang relatif tinggi. Sebaliknya keterbatasan pengalaman bekerja yang dimiliki akan makin rendah tingkat keahlian dan ketrampilan yang dimiliki; (c) Faktor Kesehatan Fisik dan Mental, faktor kesehatan fisik dan mental perlu mendapatkan pertimbangan dalam penempatan karyawan, meskipun kurang akurat terhadap tingkat kepercayaan terhadap hasil tes kesehatan dilakukan terutama kondisi fisik, namun secara sepintas dapat dilihat kondisi fisik karyawan yang bersangkutan untuk dipertimbangkan pada tempat mana dia diberikan tugas dan pekerjaan yang cocok baginya berdasarkan kondisi yang dimiliki; (d) Faktor Sikap, sikap merupakan bagian hakiki dari kepribadian seseorang. Dalam penempatan karyawan faktor sikap hendaknya menjadi pertimbangan bagi manajer sumber daya manusia, karena hal tersebut akan berpengaruh secara langsung baik bagi individu dan perusahaan maupun bagi masyarakat sebagai pengguna jasa dari perusahaan itu sendiri; (e) Faktor Status Perkawinan, untuk mengetahui status perkawinan karyawan kerja adalah merupakan hal yang penting. Dengan mengetahui status perkawinannya dapat ditentukan, dimana seseorang akan ditempatkan. Misalkan karyawan yang belum menikah ditempatkan di cabang perusahaan di luar kota dan sebaliknya karyawan yang sudah menikah ditempatkan pada perusahaan di dalam kota dimana keluarganya bertempat tinggal; dan (f) Faktor Usia, faktor usia perlu dipertimbangkan dengan maksud untuk menghindarkan rendahnya produktifitas yang dihasilkan oleh karyawan yang bersangkutan. Biasanya karyawan yang usianya sudah tua akan memiliki tingkat produktivitas yang lebih rendah dibandingkan dengan karyawan yang usianya lebih muda

\section{Pandangan Islam \\ Penempatan Karyawan}

Terhadap

Menurut ajaran Islam suatu pekerjaan merupakan tanggung jawab atau amanah ilmiah dan oleh karena itu hendaknya diberikan kepada yang tepat dan tanggung jawab hendaknya diberikan kepada orang yang mampu memikulnya dan yang mempunyai kemampuan untuk 
bertindak adil atas amanah yang dipercayakan kepadanya.

Oleh karena itu seharusnya manusia menolak tugas dan urusan-urusan yang tidak mampu dilaksanakan. Rasulullah SAW bersabda yang artinya : "Orang Mukmin seharusnya tidak menjerumuskan dirinya sendiri (pada kesulitan). Sahabat bertanya, 'bagaimana dia menjerumuskan dirinya sendiri ?' Rasul menjawab, dia memikulkan pada dirinya urusan-urusan yang tidak mampu dipikulnya".

Pekerjaan merupakan suatu amanat wajib diberikan kepada orang yang berhak menerimanya, begitu juga dalam menempatkan karyawan pada suatu pekerjaan tertentu harus dilihat dahulu apakah orang tersebut benar-benar mempunyai kemampuan dalam mengerjakan semua pekerjaan yang menjadi tanggung jawabnya atau tidak karena pekerjaan juga merupakan amanat yang harus dipegang oleh penerimanya.

\section{Kinerja}

Menurut Mangkunegara (2000: 67), kinerja adalah hasil secara kualitas dan kuantitas yang dicapai oleh seorang pegawai dalam melaksanakan tugasnya sesuai dengan tanggung jawab yang diberikan kepadanya. Kemudian Hasibuan (2001 : 69) mengemukakan kinerja adalah suatu usaha meningkatkan kemampuan, teknis, teoritis, konseptual dan moral pegawai sesuai dengan kebutuhan pekerjaan atau jabatan dengan tujuan untuk meningkatkan keterampilan teknis melaksanakan pekerjaan pegawai.

Ada dua faktor yang mempengaruhi kinerja karyawan, yaitu: (a) Faktor Kemampuan yaitu perlunya penempatan karyawan pada pekerjaan yang sesuai dengan keahliannya; dan (b) Faktor Motivasi, kondisi yang menggerakkan diri karyawan yang terarah untuk mencapai tujuan organisasi (tujuan kerja) yang merupakan dorongan yang timbul dari dalam diri pegawai untuk melakukan kegiatan atau tugas dengan sebaik-baiknya agar mampu mencapai prestasi kerja (kinerja) dengan predikat terpuji (Mangkunegara, 2000 : 67-68).

\section{Pandangan Islam Terhadap Kinerja}

Kerja sebagai sumber nilai manusia berarti manusia itu sendiri menentukan nilai atau harga terhadap usahanya sendiri. Manusia tidak akan mendapatkan hasil yang baik kecuali terhadap apa yang ia kerjakan. Kerja juga merupakan sumber yang objektif bagi penilai kinerja manusia berasaskan segi kelayakan. Islam menentukan ukuran dan syarat-syarat kelayakan dan juga syarat-syarat kegiatan bagi menentukan suatu pekerjaan dan tanggung jawab itu supaya dapat dinilai prestasi kerjanya. Dengan hal ini, Islam menyingkirkan perasaan pilih kasih dalam menilai prestasi seseorang baik dari segi sosial, ekonomi dan politik.

Islam menjadikan kerja sebagai sumber nilai insan dan ukuran yang tanggung jawab berbeda. Allah berfirman:

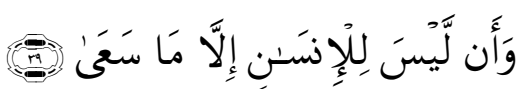

Artinya: "Dan bahwa sesungguhnya tidak ada balasan bagi seseorang itu melainkan balasan apa yang diusahakan". (QS. Al-Najm, 53: 39)

Rasulullah SAW juga bersabda dalam hadits yang diriwayatkan $\mathrm{Al}$ Bukhari yang artinya : "Tidaklah ada makanan seseorang itu yang lebih baik daripada apa yang dimakannya dari hasil usaha tangannya sendiri" (HR. Bukhari).

Al-Qur'an menanamkan kesadaran bahwa dengan bekerja berarti kita merealisasikan fungsi kehambaan kita kepada Allah, dan menempuh jalan menuju ridha-Nya, mengangkat harga diri, meningkatkan taraf hidup, dan memberi manfaat kepada sesama, bahkan kepada makhluk lain. Dengan tertanamnya kesadaran ini, seorang muslim atau muslimah akan berusaha mengisi setiap ruang dan waktunya hanya dengan aktivitas yang berguna. Semboyannya 
adalah "tiada waktu tanpa kerja, tiada waktu tanpa amal."

Berikut ini adalah kualitas etos kerja yang terpenting untuk dipedomani: (1) Baik dan Bermanfaat. Islam hanya memerintahkan atau menganjurkan pekerjaan yang baik dan bermanfaat bagi kemanusiaan, agar setiap pekerjaan mampu memberi nilai tambah dan mengangkat derajat manusia baik secara individu maupun kelompok. Allah SWT berfirman:

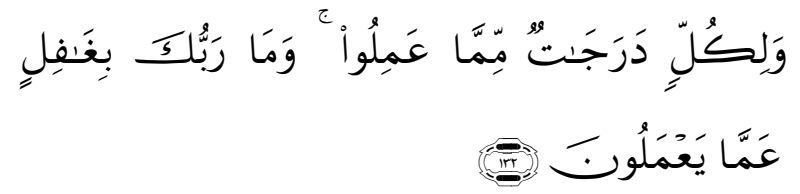

Artinya: "Dan masing-masing orang
memperoleh derajat-derajat
(seimbang) dengan apa yang
dikerjakannya." (Al-An'am, 6:
132).

Ini adalah pesan iman yang membawa manusia kepada orientasi nilai dan kualitas. Al Qur'an menggandengkan iman dengan amal soleh sebanyak 77 kali. Pekerjaan yang standar adalah pekerjaan yang bermanfaat bagi individu dan masyarakat, secara material dan moralspiritual. Tolok ukurnya adalah pesan syariah yang semata-mata merupakan rahmat bagi manusia. Jika tidak diketahui adanya pesan khusus dari agama, maka seseorang harus memperhatikan pengakuan umum bahwa sesuatu itu bermanfaat, dan berkonsultasi kepada orang yang lebih tahu. Jika hal ini pun tidak dilakukan, minimal kembali kepada pertimbangan akal sehat yang didukung secara nurani yang sejuk, lebih-lebih jika dilakukan melalui media shalat meminta petunjuk (istikharah). Dengan prosedur ini, seorang muslim tidak perlu bingung atau ragu dalam memilih suatu pekerjaan; (2) Kemantapan atau perfectness, Kualitas kerja yang itqan atau perfect merupakan sifat pekerjaan Tuhan, kemudian menjadi kualitas pekerjaan yang islami. Rahmat Allah SWT telah dijanjikan bagi setiap orang yang bekerja secara itqan, yakni mencapai standar ideal secara teknis. Untuk itu, diperlukan dukungan pengetahuan dan skill yang optimal. Dalam konteks ini, Islam mewajibkan umatnya agar terus menambah atau mengembangkan ilmunya dan tetap berlatih. Suatu keterampilan yang sudah dimiliki dapat saja hilang, akibat meninggalkan latihan, padahal manfaatnya besar untuk masyarakat. Karena itu, melepas atau menterlantarkan ketrampilan tersebut termasuk perbuatan dosa. Konsep itqan memberikan penilaian lebih terhadap hasil pekerjaan yang sedikit atau terbatas, tetapi berkualitas, daripada output yang banyak, tetapi kurang bermutu; (3) Melakukan yang Terbaik atau Lebih Baik Lagi. Kualitas ihsan mempunyai dua makna dan memberikan dua pesan, yaitu sebagai berikut. Pertama, ihsan berarti 'yang terbaik' dari yang dapat dilakukan. Dengan makna pertama ini, maka pengertian ihsan sama dengan 'itqan'. Pesan yang dikandungnya ialah agar setiap muslim mempunyai komitmen terhadap dirinya untuk berbuat yang terbaik dalam segala hal yang ia kerjakan. Kedua, ihsan mempunyai makna 'lebih baik' dari prestasi atau kualitas pekerjaan sebelumnya. Makna ini memberi pesan peningkatan yang terus-menerus, seiring dengan bertambahnya pengetahuan, pengalaman, waktu, dan sumber daya lainnya. Adalah suatu kerugian jika prestasi kerja hari ini menurun dari hari kemarin, sebagaimana dinyatakan dalam sebuah hadits Nabi SAW keharusan berbuat yang lebih baik juga berlaku ketika seorang muslim membalas jasa atau kebaikan orang lain. Bahkan, idealnya ia tetap berbuat yang lebih baik, hatta ketika membalas keburukan orang lain. Semangat kerja yang ihsan ini akan dimiliki manakala seseorang bekerja dengan semangat ibadah, dan dengan kesadaran bahwa dirinya sedang dilihat oleh Allah SWT; (4) Kerja Keras dan 
Optimal Dalam banyak ayatnya, Al-Qur'an meletakkan kulaitas mujahadah dalam bekerja pada konteks manfaatnya, yaitu untuk kebaikan manusia sendiri, dan agar nilai guna dari hasil kerjanya semakin bertambah. Mujahadah dalam maknanya yang luas seperti yang didefinisikan oleh Ulama adalah "istifragh ma fil wus'i", yakni mengerahkan segenap daya dan kemampuan yang ada dalam merealisasikan setiap pekerjaan yang baik. Dapat juga diartikan sebagai mobilisasi serta optimalisasi sumber daya. Sebab, sesungguhnya Allah SWT telah menyediakan fasilitas segala sumber daya yang diperlukan melalui hukum 'taskhir', yakni menundukkan seluruh isi langit dan bumi untuk manusia. Tinggal peran manusia sendiri dalam memobilisasi serta mendaya gunakannya secara optimal, dalam rangka melaksanakan apa yang Allah ridhai. Bermujahadah atau bekerja dengan semangat jihad (ruhul jihad) menjadi kewajiban setiap muslim dalam rangka tawakkal sebelum menyerahkan (tafwidh) hasil akhirnya pada keputusan Allah.

Adapun hipotesis penelitian ini adalah: "Diduga Bahwa Rekrutmen dan Penempatan Karyawan Pada Hotel Oase Pekanbaru Berpengaruh Terhadap Kinerja Karyawan"

Adapun yang menjadi variabel pada penelitian ini terdiri dari variabel independen dan variabel dependen. Variabel independen (X1) yaitu Rekrutmen, (X2) yaitu Penempatan dan Variabel dependen (Y) yaitu Kinerja Karyawan.

\section{METODE}

Lokasi penelitian ini dilakukan di Hotel Oase yang terletak di jalan Jendral Sudirman No. 255 EF (Simpang Jl. K.H. Wahid Hasyim) Pekanbaru.

Adapun jenis dan sumber data yang digunakan adalah sebagai berikut: (a) Data Primer, yaitu data yang diperoleh dari objek penelitian melalui wawancara langsung dengan karyawan / responden, bagian umum mengenai data pelaksanaan rekrutmen karyawan, dan Jawaban responden melalui kuisioner yang disebarkan; dan (b) Data Sekunder, yaitu data yang telah jadi dan tersedia pada perusahaan seperti data mengenai sejarah singkat perusahaan, struktur organisasi dan aktivitas karyawan, jumlah karyawan yang diterima dan jumlah pelamar, data penempatan karyawan.

Adapun metode yang digunakan dalam pengumpulan data adalah sebagai berikut: (a) Wawancara (Interview) yaitu suatu pengumpulan data dengan menanyakan langsung kepada pimpinanan dan karyawan untuk mendapatkan informasi yang dibutuhkan pertanyaan objek penelitian; dan (b) Daftar Pertanyaan (Quesioner) yaitu metode pengumpulan data dengan jalan membuat daftar pertanyaan yang kemudian diajukan kepada pimpinan dan karyawan yang ditemui guna melengkapi data dan informasi yang diperoleh untuk tercapainya tujuan penelitian ini.

Adapun responden yang akan diteliti diperusahaan Hotel Oase Pekanbaru adalah seluruh manajemen dan karyawan yang berjumlah sebanyak 30 orang. Metode yang digunakan pada penelitian ini adalah metode sensus.

Untuk menganalisa data penulis menggunakan metode regresi linear berganda, yaitu suatu metode statistik yang digunakan untuk mengetahui hubungan antara variabel bebas dan terikat yang dibantu dengan menggunakan program SPSS Versi 17.0. Analisis regresi linear berganda memberikan kemudahan bagi pengguna untuk memasukan lebih dari satu variabel yang ditunjukan dengan persamaan:

$$
\begin{aligned}
& \mathbf{Y =} \mathbf{a}+\mathbf{b}_{1} \mathbf{X}_{\mathbf{1}}+\mathbf{b}_{2} \mathbf{X}_{\mathbf{2}}+\mathbf{e} \\
& \text { Ket: } \mathrm{Y}=\text { Kinerja } \\
& \\
& \mathbf{a}=\text { Konstanta } \mathrm{b}_{1} \\
& \mathrm{~b}_{2,}=\text { Koefisien Regresi, } \\
& \mathrm{X}_{1}=\text { Rekrutmen, } \\
& \mathrm{X}_{2}=\text { Penempatan Kerja }
\end{aligned}
$$


$\mathrm{e}=$ Tingkat kesalahan (eror)

Pengukuran variabel-variabel yang terdapat dalam model analisis penelitian ini bersumber dari jawaban atas pertanyaan yang terdapat dalam angket. Karena semua jawaban tersebut bersifat kualitatif sehingga dalam analisa sifat kualitatif tersebut diberi nilai agar menjadi data kuantitatif. Penentuan nilai jawaban untuk setiap pertanyaan di gunakan metode Skala Likert. Pembobotan setiap pertayaan adalah sebagai berikut: 1) Jika memilih jawaban Sangat Setuju (SS), maka diberi nilai 5 2) Jika memilih jawaban Setuju (S), maka diberi nilai 4. 3) Jika memilih jawaban Netral (NT), maka diberi nilai 3 4) Jika memilih jawaban Tidak Setuju (TS), maka diberi nilai 2, 5)Jika memilih jawaban Sangat Tidak Setuju (STS), maka diberi nilai 1

Uji Siqnifikansi Secara Parsial ( uji statistik t ), Uji siqnifikansi secara parsial (uji statistik t) ini bertujuan untuk mengatahui seberapa besar pengaruh variabel indenpenden $\mathrm{X}_{1}$ dan $\mathrm{X}_{2}$ terhadap variabel dependen (Y) dengan asumsi variabel lainya adalah konsta. Pengujian dilakukan dengan 2 arah (2 tail) dengan tingkat keyakinan sebesar $95 \%$ dan dilakukan uji tingkat signifikan pengaruh hubungan variabel independen secara individual terhadap variabel dependen, dimana tingkat signifikansi ditentukan sebesar $5 \%$ dan degree of freedom $(\mathrm{df})=\mathrm{n}$ $-\mathrm{k}$.

Adapun kriteria pengambilan keputusan yang digunakan dalam pengujian ini adalah apabila $t_{\text {hitung }}>t_{\text {tabel, }}$ maka hipotesis diterima, dengan kata lain variabel independen secara individual memiliki pengaruh yang signifikan terhadap variabel dependen. Sebaliknya, jika $t_{\text {hitung }}<t_{\text {tabel }}$ maka hipotesis ditolak.

\section{HASIL}

\section{Gambaran Umum Hotel Oase Pekanbaru}

Perhotelan memiliki hubungan erat dengan dunia pariwisata karena tanpa adanya hotel dan sarana akomodasi lainnya, industri pariwisata tidak akan berkembang. Salah satu sarana yang tersedia adalah Hotel Oase yang berlokasi di jalan jendral Sudirman No. 255 EF diklasifikasikan sebagai hotel berkelas melati.

Hotel Oase berdiri 1 januari 2006 dan terus berkembang hingga sekarang. Hotel Oase memiliki perizinan yang resmi yaitu, izin tempat usaha jenis UU gangguan, izin usaha, SK Notaris dan PPAT Azhari, SH, Tanda Daftar Perusahaan (TDP), izin pengendalian pembuangan limbah cair dan izin lainnya.

Hotel Oase memiliki motto "aman, nyaman dan bermartabat" sehingga tamu atau pengunjung hotel merasakan prestise hotel berkualitas. Pada awal beroperasi secara efektif, hotel Oase mempunyai 23 kamar dan sampai sekarang terus melakukan inovasi terbaiknya. Saat ini hotel Oase mempunyai 38 kamar dan memiliki fasilitas ruangan yaitu pendingin udara, televisi warna, kamar mandi dengan air panas dan dingin, minibar, telepon, comfortable springbed, air mineral.

Hotel Oase memiliki fasilitas antara lain area parkir yang luas buat pengunjung dan tamu hotel, lobi yang nyaman dan sejuk dilengkapi dengan Wi Fi, coffe shop, lift, laundry, safe deposit box, penyewaan mobil dan taksi. Untuk ruang pertemuan hotel Oase mampu menampung hingga puluhan orang, bisa diatur sesuai dengan kebutuhan dan permintaan dan dilengkapi sound system, flip chart dan paper pad, whiteboard, OHP plus screen serta air mineral dan candy.

Pihak manajemen hotel Oase menerapkan manajemen yang selektif dalam menerima pengunjung atau tamu hotel. Dengan selektifnya menerima tamu diharapkan tamu-tamu hotel bermartabat dan mamiliki prestise.

Adapun tarif kamar yang berlaku di Hotel Oase mulai dari Rp 198 ribu untuk tipe Studio, Rp 250 ribu untuk tipe Junior, 
Rp 300 ribu untuk tipe Senior, Rp 400 ribu untuk tipe Suite.

Pada struktur organisasi Hotel Oase Pekanbaru terdiri dari beberapa bagian atau departemen yang bertugas mengurus bidangnya masing-masing, bertanggungjawab terhadap pimpinan perusahaan. Setiap bagian mempunyai tugas dan tanggungjawab serta wewenang yang telah dituangkan dalam job description. Berdasarkan struktur di atas dapat diuraikan fungsi dan wewenang dari masing-masing: (1) General Manager, merupakan pimpinan atau manejer hotel Oase Pekanbaru untuk melaksanakan tugas operasional; (2) Accounting, mengecek laporan pendapatan per hari, membuat laporan keuangan per bulan, membuat laporan pengeluaran, membuat daftar gaji, melakukan audit inventaris; dan (3) House Keeping, untuk menunjang kelancaran tugas sehari-hari dan agar dapat menjangkau seluruh tugas.

House Keeping Department di bagi menjadi beberapa seksi menurut areal tugas masing-masing, untuk itu House Keeping Department dibagi menjadi: (a) Floor Section (Room Section), Floor Section sering juga disebut sebagai Room Section. Tugas pokok dari bagian ini ialah menjaga dan mempersiapkan kebersihan, kerapian, keindahan, kenyamanan, dan kelengkapan kamar-kamar tamu. Tugas tersebut dikerjakan langsung oleh seorang Room Boy (pramugraha); (b) Houseman Section (Public Area Section), tugas pokok dari pada seksi ini ialah menjaga kebersihan, kerapian, keindahan dan kenyamanan seluruh area hotel, baik yang ada di luar gedung maupun di dalam gedung kecuali kamar tamu; (c). Linnen Uniform Section Adalah seksi yang bertanggung jawab untuk mengelola sirkulasi dan penyediaan seluruh linen dan uniform bagi karyawan; (d) Laundry Section adalah seksi yang mempunyai tanggung jawab untuk menyediakan linen-linen yang bersih untuk keperluaan kamar, restauran dan meeting room, menyediakan seragam bersih bagi karyawan dan membersihkan pakaian tamu yang kotor; (e) Front Office Fungsi pokok front office sebagai berikut: (1) menerima dan menangani pemesanan kamar; (2) Menangani kedatangan dan keberangkatan tamu dan barang; (3) meregistrasi kedatangan tamu. Fungsi lain dari front office: (1) Menyediakan informasi layanan hotel, meliputi: Informasi mengenai operasi hotel dan Kantor Depan. Informasi tambahan di luar operasi hotel (lokasi, acara/pertunjukan); (2) Mengadakan koordinasi layanan tamu, meliputi: Hubungan antara para petugas di depan dan di belakang. Menangani masalah atau keluhan tamu; (3) Menangani pembayaran hotel, meliputi: Menyimpan bill/cek tamu. Menerima pembayaran tunai atau kredit Membuat laporan/rekapitulasi penerimaan; dan (4) Menangani layanan lainnya, seperti: Menangani surat, kunci, panggilan atau pesan tamu. Menangani telepon, telegram, telex, dan facsimile serta alat komunikasi lainya. Food and Baverage yaitu departemen yang menangani makan dan minuman di hotel, baik untuk tamu maupun untuk karyawan. Engineering mempunyai tugas mengurusi masalah mesin, listrik, elektronik maintenance. Security menjaga keamanan dalam area hotel baik pada tamu maupun pada aset hotel, dan mengatur parkir kendaraan tamu atau pengunjung hotel.

\section{Deskripsi Rekrutmen}

Rekrutmen adalah suatu proses untuk menentukan sumber - sumber tenaga kerja yang potensi yang diperlukan perusahaan dan mencari calon karyawan dari sumbernya. 
Tabel 3

Rekapitulasi tanggapan responden terhadap variabel Rekrutmen ( $\left.\mathrm{X}_{1}\right)$

\begin{tabular}{|c|c|c|c|c|c|c|c|}
\hline \multirow{2}{*}{ No } & \multirow{2}{*}{ Pernyataan } & \multicolumn{5}{|c|}{ Frekuensi } & \multirow{2}{*}{ Jumlah } \\
\hline & & SS & $S$ & NT & TS & STS & \\
\hline \multirow[t]{2}{*}{1} & $\begin{array}{l}\text { Proses penyeleksian } \\
\text { dokumen sangat ketat }\end{array}$ & 13 & 15 & 2 & 0 & 0 & 30 \\
\hline & & $43,3 \%$ & $50,0 \%$ & $6,67 \%$ & $0,00 \%$ & $0,00 \%$ & $100 \%$ \\
\hline \multirow[t]{2}{*}{2} & $\begin{array}{l}\text { Psikotes dilakukan dengan } \\
\text { baik }\end{array}$ & 14 & 11 & 3 & 2 & 0 & 30 \\
\hline & & $46,7 \%$ & $36,7 \%$ & $10,0 \%$ & $6,67 \%$ & $0,00 \%$ & $100 \%$ \\
\hline \multirow[t]{2}{*}{3} & $\begin{array}{lr}\text { Pelaksanaan } & \text { Tes } \\
\text { intelegensi ditangani } & \text { oleh } \\
\text { pakarnya } & \end{array}$ & 10 & 19 & 1 & 0 & 0 & 30 \\
\hline & & $33,3 \%$ & $63,3 \%$ & $3,33 \%$ & $0,00 \%$ & $0,00 \%$ & $100 \%$ \\
\hline \multirow[t]{2}{*}{4} & $\begin{array}{l}\text { Tes kepribadian dilakukan } \\
\text { sangat teliti }\end{array}$ & 15 & 13 & 2 & 0 & 0 & 30 \\
\hline & & $50,0 \%$ & $43,3 \%$ & $6,67 \%$ & $0,00 \%$ & $0,00 \%$ & $100 \%$ \\
\hline \multirow[t]{2}{*}{5} & $\begin{array}{l}\text { Melakukan tes bakat dan } \\
\text { kemampuan untuk } \\
\text { mengukur dan menilai } \\
\text { mana yang sesuai dengan } \\
\text { bidang pekerjaan yang } \\
\text { dibutuhkan }\end{array}$ & 9 & 5 & 5 & 10 & 1 & 30 \\
\hline & & $30,0 \%$ & $16,7 \%$ & $16,7 \%$ & $33,3 \%$ & $3,33 \%$ & $100 \%$ \\
\hline \multirow[t]{2}{*}{6} & \begin{tabular}{lr} 
Tes & \multicolumn{2}{r}{ kesehatan } \\
dilaksanakan & oleh para \\
medis &
\end{tabular} & 8 & 7 & 6 & 9 & 0 & 30 \\
\hline & & $26,7 \%$ & $23,3 \%$ & $20,0 \%$ & $30,0 \%$ & $0,00 \%$ & $100 \%$ \\
\hline \multirow[t]{2}{*}{7} & $\begin{array}{lr}\begin{array}{l}\text { Kondisi } \\
\text { pada }\end{array} & \text { perdampak } \\
\text { pekerjaan } & \\
\end{array}$ & 18 & 12 & 0 & 0 & 0 & 30 \\
\hline & & $60,0 \%$ & $40,0 \%$ & $0,00 \%$ & $0,00 \%$ & $0,00 \%$ & $100 \%$ \\
\hline \multirow[t]{2}{*}{8} & $\begin{array}{lr}\text { Metode } & \text { rekrutmen } \\
\text { berpengaruh } & \text { kepada } \\
\text { kinerja } & \\
\end{array}$ & 13 & 14 & 3 & 0 & 0 & 30 \\
\hline & & $43,3 \%$ & $46,7 \%$ & $10,0 \%$ & $0,00 \%$ & $0,00 \%$ & $100 \%$ \\
\hline 9 & $\begin{array}{l}\text { Pelaksanaan wawancara } \\
\text { dilakukan secara objektif }\end{array}$ & 16 & 13 & 1 & 0 & 0 & 30 \\
\hline & Jumlah & 116 & 109 & 23 & 21 & 1 & 270 \\
\hline & Rata-rata & 13 & 12 & 3 & 2 & $\mathbf{0}$ & 30 \\
\hline & Persentase & $43,3 \%$ & $\begin{array}{r}40,0 \\
\%\end{array}$ & $\begin{array}{r}10,0 \\
\%\end{array}$ & $\begin{array}{r}6,00 \\
\%\end{array}$ & $00,0 \%$ & $100 \%$ \\
\hline
\end{tabular}

Berdasarkan tabel rekapitulasi jawaban responden tentang variabel rekrutmen di atas, menunjukan bahwa sebanyak 13 orang atau sebesar 43,3\% menyatakan sangat setuju, selanjutnya sebanyak 12 orang atau sebesar 40,0\% responden menyatakan setuju, kemudian sebanyak 3 orang atau sebesar 10,0 \% responden menyatakan kurang setuju, sebanyak 2 orang atau sebesar $6,00 \%$ responden menyatakan tidak setuju.

\section{Deskripsi Penempatan}

Penempatan tenaga kerja merupakan proses pemberian tugas dan pekerjaan kepada tenaga kerja yang telah lulus seleksi untuk dilaksanakan sesuai ruang lingkup yang telah 
ditetapkan serta mampu mempertanggungjawabkan segala resiko dan kemungkinan-kemungkinan yang terjadi atas tugas dan pekerjaan, wewenang, serta tanggung jawabnya.

\section{Tabel 4}

Rekapitulasi tanggapan responden terhadap variabel Penempatan $\left(X_{2}\right)$

\begin{tabular}{|c|c|c|c|c|c|c|c|}
\hline \multirow{2}{*}{ No } & \multirow{2}{*}{ Pernyataan } & \multicolumn{5}{|c|}{ Frekuensi } & \multirow{2}{*}{ Jumlah } \\
\hline & & SS & $S$ & NT & TS & STS & \\
\hline \multirow[t]{2}{*}{1} & $\begin{array}{lr}\text { Sistem r penempatan } \\
\text { disesuaikan } & \text { dengan } \\
\text { prestasi akademis }\end{array}$ & 10 & 12 & 8 & 0 & 0 & 30 \\
\hline & & $33,3 \%$ & $40,0 \%$ & $26,7 \%$ & $0,00 \%$ & $0,00 \%$ & $100 \%$ \\
\hline \multirow[t]{2}{*}{2} & $\begin{array}{lr}\text { Penempatan } & \text { kerja } \\
\text { disesuaikan } & \text { dengan } \\
\text { pengalaman } & \text { kerja yang } \\
\text { dimiliki } & \end{array}$ & 20 & 10 & 0 & 0 & 0 & 30 \\
\hline & & $66,7 \%$ & $33,3 \%$ & $0,00 \%$ & $0,00 \%$ & $0,00 \%$ & $100 \%$ \\
\hline \multirow[t]{2}{*}{3} & $\begin{array}{l}\text { Jaminan kesehatan anda } \\
\text { telah sesuai }\end{array}$ & 3 & 7 & 8 & 12 & 0 & 30 \\
\hline & & $10,0 \%$ & $23,3 \%$ & $26,7 \%$ & $40,0 \%$ & $0,00 \%$ & $100 \%$ \\
\hline \multirow[t]{2}{*}{4} & $\begin{array}{l}\text { Penempatan kerja sesuai } \\
\text { dengan usia anda saat ini }\end{array}$ & 9 & 20 & 1 & 0 & 0 & 30 \\
\hline & & $30,0 \%$ & $66,7 \%$ & $3,33 \%$ & $0,00 \%$ & $0,00 \%$ & $100 \%$ \\
\hline \multirow[t]{2}{*}{5} & $\begin{array}{l}\text { Usia sangat berpengaruh } \\
\text { terhadap produktivitas } \\
\text { kerja yang dihasilkan }\end{array}$ & 10 & 11 & 4 & 5 & 0 & 30 \\
\hline & & $33,3 \%$ & $36,7 \%$ & $13,3 \%$ & $16,7 \%$ & $0,00 \%$ & $100 \%$ \\
\hline \multirow[t]{2}{*}{6} & $\begin{array}{lr}\text { Status } & \text { perkawinan } \\
\text { menjadi pertimbangan } \\
\text { dimana anda ditempatkan }\end{array}$ & 13 & 12 & 0 & 3 & 2 & 30 \\
\hline & & $43,3 \%$ & $40,0 \%$ & $0,00 \%$ & $10,0 \%$ & $6,67 \%$ & $100 \%$ \\
\hline \multirow[t]{5}{*}{7} & $\begin{array}{l}\text { Pekerjaan anda sesuai } \\
\text { dengan sikap dan prilaku }\end{array}$ & 16 & 12 & 2 & 0 & 0 & 30 \\
\hline & & $53,3 \%$ & $40,0 \%$ & $6,67 \%$ & $0,00 \%$ & $0,00 \%$ & $100 \%$ \\
\hline & Jumlah & 81 & 84 & 23 & 20 & 2 & 210 \\
\hline & Rata-rata & 11 & 12 & 4 & 3 & $\mathbf{0}$ & 30 \\
\hline & Persentase & $36,7 \%$ & $40,0 \%$ & $13,3 \%$ & $10,0 \%$ & $0,00 \%$ & $100 \%$ \\
\hline
\end{tabular}

Berdasarkan tabel rekapitulasi jawaban responden tentang variabel penempatan di atas, menunjukan bahwa sebanyak 11 orang atau sebesar 36,7 \% responden menyatakan sangat setuju, selanjutnya sebanyak 12 orang atau sebesar 40,0 \% responden menyatakan setuju, kemudian sebanyak 4 orang atau sebesar $13,3 \%$ responden menyatakan netral, selanjutnya sebanyak 3 orang atau sebesar $10,0 \%$ responden menyatakan tidak setuju.

\section{Deskripsi Kinerja}

Kinerja sebagai suatu keadaan yang menunjukkan kemampuan seseorang karyawan dalam menjalankan tugas sesuai dengan standar yang telah ditentukan oleh organisasi kepada karyawannya sesuai dengan job description-nya. Selanjutnya kinerja adalah suatu kemampuan apa saja yang telah dicapai serta kualitas kerja karyawan untuk memperbaiki dan meningkatkan kerjanya di masa yang akan datang. 
Tabel 5

Rekapitulasi tanggapan responden terhadap variabel Kinerja (Y).

\begin{tabular}{|c|c|c|c|c|c|c|c|}
\hline \multirow{2}{*}{ No } & \multirow{2}{*}{ Pernyataan } & \multicolumn{5}{|c|}{ Frekuensi } & \multirow{2}{*}{ Jumlah } \\
\hline & & SS & $\mathbf{S}$ & NT & TS & STS & \\
\hline \multirow[t]{2}{*}{1} & $\begin{array}{l}\text { Motivasi yang diberikan } \\
\text { atasan menambah } \\
\text { semangat saudara untuk } \\
\text { lebih giat bekerja }\end{array}$ & 10 & 17 & 3 & 0 & 0 & 30 \\
\hline & & $33,3 \%$ & $56,7 \%$ & $10,0 \%$ & $0,00 \%$ & $0,00 \%$ & $100 \%$ \\
\hline \multirow[t]{2}{*}{2} & $\begin{array}{lr}\begin{array}{l}\text { Tugas dan } \\
\text { saudara }\end{array} & \text { pekerjaan } \\
\text { dengan baik } & \end{array}$ & 7 & 6 & 4 & 10 & 3 & 30 \\
\hline & & $23,3 \%$ & $20,0 \%$ & $13,3 \%$ & $33,3 \%$ & $10,0 \%$ & $100 \%$ \\
\hline \multirow[t]{2}{*}{3} & $\begin{array}{l}\text { Atasan puas dengan hasil } \\
\text { kerja saudara }\end{array}$ & 6 & 15 & 9 & 0 & 0 & 30 \\
\hline & & $20,0 \%$ & $50,0 \%$ & $30,0 \%$ & $0,00 \%$ & $0,00 \%$ & $100 \%$ \\
\hline \multirow[t]{2}{*}{4} & $\begin{array}{l}\text { Secara keseluruhan sistem } \\
\text { penilaian kinerja sangat } \\
\text { baik }\end{array}$ & 9 & 6 & 3 & 12 & 0 & 30 \\
\hline & & $30,0 \%$ & $20,0 \%$ & $10,0 \%$ & $40,0 \%$ & $0,00 \%$ & $100 \%$ \\
\hline \multirow[t]{2}{*}{5} & $\begin{array}{l}\text { Gaji yang besar memberi } \\
\text { motivasi anda bekerja dg } \\
\text { baik }\end{array}$ & 19 & 11 & 0 & 0 & 0 & 30 \\
\hline & & $63,3 \%$ & $36,7 \%$ & $0,00 \%$ & $0,00 \%$ & $0,00 \%$ & $100 \%$ \\
\hline \multirow[t]{5}{*}{6} & $\begin{array}{l}\text { Anda bekerja sesuai } \\
\text { dengan kemampuan yang } \\
\text { anda miliki }\end{array}$ & 10 & 9 & 11 & 0 & 0 & 30 \\
\hline & & $33,3 \%$ & $30,0 \%$ & $\%$ & $0,00 \%$ & $0,00 \%$ & $100 \%$ \\
\hline & Jumlah & 61 & 64 & 30 & 22 & 3 & 180 \\
\hline & Rata-rata & 10 & 11 & 5 & 4 & 0 & 30 \\
\hline & Persentase & $33,3 \%$ & $36,7 \%$ & $16,7 \%$ & $13,3 \%$ & $0,00 \%$ & $100 \%$ \\
\hline
\end{tabular}

Berdasarkan tabel rekapitulasi jawaban responden tentang variabel produktivitas kerja di atas, menunjukan bahwa sebanyak 10 orang atau sebesar $33,3 \%$ responden menyatakan sangat setuju, selanjutnya sebanyak 11 orang atau sebesar $36,7 \%$ responden menyatakan setuju, kemudian sebanyak 5 orang atau sebesar 16,7 \% responden menyatakan netral, selanjutnya sebanyak
4 orang atau sebesar 13,3\% responden menyatakan tidak setuju.

\section{Uji Kualitas Data}

Sebelum dilakukan analisis data dengan menggunakan program SPSS, maka terlebih dahulu dilakukan uji kualitas data dan uji asumsi klasik.

Berikut tabel tentang hasil uji validitas dari butiran-butiran pernyataan responden penelitian:

Tabel 6

Rekapitulasi Uji Validitas untuk setiap penyataan Rekrutmen $\left(\mathrm{X}_{11}-\mathrm{X}_{19}\right)$, Penempatan $\left(\mathrm{X}_{21}-\mathrm{X}_{27}\right)$, dan Kinerja $\left(\mathrm{Y}_{31}-\mathrm{Y}_{36}\right)$

\begin{tabular}{ccccc}
\hline Variabel & $\begin{array}{c}\text { Corrected } \\
\text { Item Total }\end{array}$ & Tanda & Nilai & Ket \\
\hline
\end{tabular}




\section{Correlation}

\begin{tabular}{ccccc}
\hline Rekrutmen $\left(\mathrm{X}_{1}\right)$ & & & & \\
\hline $\mathrm{X}_{11}$ & 0,540 & $>$ & 0,3 & Valid \\
\hline $\mathrm{X}_{12}$ & 0,551 & $>$ & 0,3 & Valid \\
\hline $\mathrm{X}_{13}$ & 0,353 & $>$ & 0,3 & Valid \\
\hline $\mathrm{X}_{14}$ & 0,378 & $>$ & 0,3 & Valid \\
\hline $\mathrm{X}_{15}$ & 0,420 & $>$ & 0,3 & Valid \\
\hline $\mathrm{X}_{16}$ & 0,441 & $>$ & 0,3 & Valid \\
\hline $\mathrm{X}_{17}$ & $>$ & 0,3 & Valid \\
\hline $\mathrm{X}_{18}$ & 0,473 & $>$ & 0,3 & Valid \\
\hline $\mathrm{X}_{19}$ & 0,321 & 0,3 & Valid \\
\hline $\mathrm{X}_{21}$ & 0,546 & & & \\
\hline $\mathrm{X}_{22}$ & & $>$ & 0,3 & Valid \\
\hline $\mathrm{X}_{23}$ & 0,666 & 0,3 & Valid \\
\hline $\mathrm{X}_{24}$ & 0,824 & 0,3 & Valid \\
\hline $\mathrm{X}_{25}$ & 0,809 & $>$ & 0,3 & Valid \\
\hline $\mathrm{X}_{26}$ & 0,695 & $>$ & 0,3 & Valid \\
\hline $\mathrm{X}_{27}$ & $>$ & 0,3 & Valid \\
\hline Kinja $(\mathrm{Y})$ & 0,746 & $>$ & 0,3 & Valid \\
\hline $\mathrm{Y}_{31}$ & 0,338 & & \\
\hline $\mathrm{Y}_{32}$ & 0,418 & $>$ & 0,3 & Valid \\
\hline $\mathrm{Y}_{33}$ & & $>$ & 0,3 & Valid \\
\hline $\mathrm{Y}_{34}$ & 0,850 & $>$ & 0,3 & Valid \\
\hline $\mathrm{Y}_{35}$ & 0,592 & 0,3 & Valid \\
\hline $\mathrm{Y}_{36}$ & 0,803 & 0,3 & Valid \\
\hline & 0,342 & & Valid \\
\hline & 0,406 & $>$ &
\end{tabular}

Berdasarkan tabel rekapitulasi Uji Validitas untuk setiap pertanyaan di atas dapat di lihat bahwa nilai Corrected Item Total Correlation atau nilai $\mathrm{r}$ hitung untuk masing-masing variabel berada $>0,3$. Ini menunjukkan bahwa data tersebut valid karena memenuhi asumsi uji validitas.

Berikut akan dilihatkan tabel tentang hasil uji reliabelitas dari butiran-butiran variabel penelitian:

\section{Tabel 7}

\section{Hasil Uji Reliabilitas}

\begin{tabular}{lcccc}
\hline \multicolumn{1}{c}{ Variabel } & Cronbach's Alpha & Tanda & Nilai & Keterangan \\
\hline Rekrutmen & 0,642 & $>$ & 0,6 & Reliabel \\
\hline Penempatan & 0,786 & $>$ & 0,6 & Reliabel \\
\hline Kinerja & 0,759 & $>$ & 0,6 & Reliabel \\
\hline
\end{tabular}

Berdasarkan tabel 7 di atas dapat diketahui bahwa nilai Cronbach's Alpha untuk masing-masing variabel berada > 0,6 . Ini menunjukkan bahwa masing- masing variabel tersebut reliabel dan layak untuk diuji.

Berikut hasil uji normalitas data model regresi penelitian: 


\section{Gambar 1}

\section{Uji Normalitas}

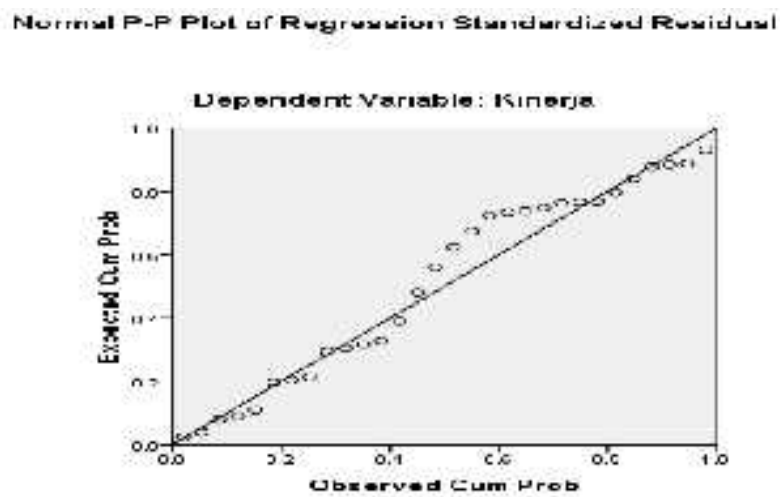

Berdasarkan gambar 1 di atas, dapat diketahui bahwa sebaran data berada di sekitar garis diagonal dan mengikuti garis diagonal. Oleh karena itu model regresi dalam penelitian ini memenuhi asumsi normalitas.

Untuk mengetahui apakah hasil estimasi regresi yang dilakukan betulbetul terbebas dari adanya gejala multikolinearitas, autokorelasi, dan gejala heterokedastisitas, perlu dilakukan pengujian yang disebut dengan uji asumsi klasik.

Tujuannya adalah untuk menguji apakah dalam model regresi ada korelasi antara kesalahan pengganggu pada periode $t$ dengan pengganggu pada periode $\mathrm{t}-1$ (sebelum data diurutkan berdasarkan urutan waktu). Model regresi yang baik adalah regresi yang bebas dari autokorelasi. Pengujian ini dilakukan dengan Durbin-Watson Test ( Tabel $D-W)$ dalam pengambilan keputusannya adalah: (1) Angka D - W di bawah - 2 berarti ada autokorelasi positif; (2) Angka D - W di antara - 2 sampai 2 berarti tidak ada autokorelasi; dan (3) Angka D - W di atas 2 berarti ada autokorelasi negatif.

Tabel 8

Rekapitulasi Uji Autokorelasi

\begin{tabular}{lcll}
\hline \multicolumn{1}{c}{ Variabel } & $\begin{array}{c}\text { Durbin } \\
\text { Watson }\end{array}$ & \multicolumn{1}{c}{$\begin{array}{c}\text { Kriteria } \\
\text { Keputusan }\end{array}$} & Keterangan \\
\hline $\begin{array}{l}\text { Rekrutmen }\left(\mathrm{X}_{1}\right) \\
\text { Penempatan }\left(\mathrm{X}_{2}\right)\end{array}$ & 1.554 & $\begin{array}{l}\text { Berada di antara }-2 \\
\text { sampai 2 }\end{array}$ & Tidak ada autokorelasi \\
\hline
\end{tabular}

Berdasarkan tabel rekapitulasi uji autokorelasi di atas, diperoleh nilai D-W untuk kedua variabel independen sebesar 1.554. Ini menunjukkan bahwa nilai D-W berada di antara - 2 sampai 2 yang artinya tidak ada autokorelasi, sehingga dapat disimpulkan bahwa tidak ada autokorelasi dalam model penelitian ini.

Uji Heteroskedastisitas bertujuan untuk menguji apakah dalam model regresi terjadi ketidaksamaan varians dan residual dari suatu pengamatan yang lain. Model regresi yang baik adalah tidak terjadi heterokedastisitas. Pengujian ini dilakukan dengan melihat pola tertentu pada grafik dimana sumbu Y adalah yang telah diprediksikan dan sumbu $\mathrm{X}$ adalah residual (Y prediksi - Y sesungguhnya) yang telah distandarkan. 


\section{Gambar 2 \\ Uji Heterokedastisitas}

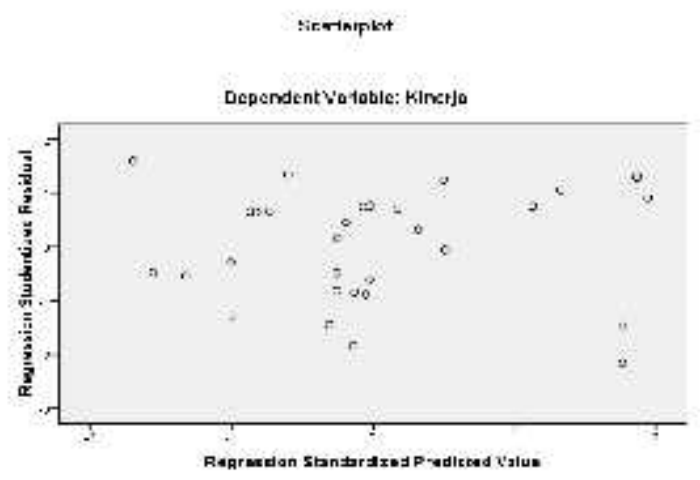

Berdasarkan gambar di atas, terlihat bahwa titik-titik menyebar secara tidak penelitian ini bebas dari acak, dan membentuk suatu pola tertentu, serta tersebar di atas dan di atas angka nol pada sumbu Y. Jadi, dapat disimpulkan bahwa model regresi dalam

heteroskedastisitas.

Hasil dari perhitungan untuk analisis regresi dari responden dapat di lihat pada tabel dibawah ini :

Tabel 9

Rekapitulasi Regresi Linear Berganda

\begin{tabular}{cc}
\hline Model & Unstandardized Coefficients \\
\cline { 2 - 2 } Konstanta & B \\
Rekrutmen $\left(\mathrm{X}_{1}\right)$ & 19.180 \\
Penempatan $\left(\mathrm{X}_{2}\right)$ & 0.051 \\
\end{tabular}

Berdasarkan tabel rekapitulasi regresi linear berganda di atas, maka diperoleh persamaan regresi yang dihasilkan adalah:

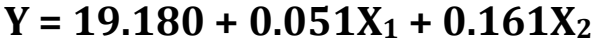

Berdasarkan persamaan regresi di atas, maka dapat dijelaskan sebagai berikut: (1) Konstanta sebesar 19.180 menyatakan bahwa jika tidak ada rekrutmen dan penempatan kerja, maka nilai kinerja karyawan pada Hotel Oase Pekanbaru akan tetap sebesar 19.180; (2) Koefisien regresi sebesar 0.051 menyatakan bahwa setiap penambahan 1 nilai rekrutmen, maka akan meningkatkan kinerja karyawan pada Hotel Oase Pekanbaru sebesar 0.051 dengan asumsi besarnya variabel dependen lainnya adalah tetap; dan (3) Koefisien regresi sebesar 0.161 menyatakan bahwa setiap penambahan 1 nilai penempatan kerja, maka akan meningkatkan kinerja karyawan pada Hotel Oase Pekanbaru sebesar 0.161 dengan asumsi besarnya variabel dependen lainnya adalah tetap.

Pengujian hipotesis yang digunakan dalam penelitian ini menggunakan Uji Secara Parsial (Uji t), Uji Secara Simultan (Uji F), dan Uji Koefisien Determinasi $\left(\mathrm{R}^{2}\right)$.

Setelah diketahui adanya pengaruh antara variabel independen terhadap variabel dependen secara bersama-sama, selanjutnya adalah dilakukan uji t statistic untuk mengetahui apakah secara parsial variabel independen berpengaruh signifikan terhadap variabel dependen. Pengujian ini dilakukan dengan membandingkan $\mathrm{t}$ 
hitung dengan $t$ tabel dengan tingkat signifikansi sebesar $5 \%$ dan degree of freedom $(\mathrm{df})=\mathrm{n}-(\mathrm{k}+1)$. Dimana apabila $\mathrm{t}$ hitung $>\mathrm{t}$ tabel, maka hipotesis diterima, dengan kata lain variabel independen secara individual memiliki pengaruh yang signifikan terhadap variabel dependen. Sebaliknya, jika $\mathrm{t}$ hitung $<\mathrm{t}$ tabel maka hipotesis ditolak.

\section{Tabel 10}

Rekapitulasi Hasil Pengujian Hipotesis Secara Parsial (Uji t)

\begin{tabular}{ccccccc}
\hline Variabel & $\mathbf{T}_{\text {hitung }}$ & Sig & Tanda & Alpha ( $\boldsymbol{\alpha})$ & Ket & Hipotesis \\
\hline Rekrutmen $\left(\mathrm{X}_{1}\right)$ & 3.380 & 0.002 & $<$ & 0.05 & Sig & $\begin{array}{l}\mathrm{H}_{0} \text { ditolak } \\
\mathrm{H}_{1} \text { diterima }\end{array}$ \\
\hline Penempatan $\left(\mathrm{X}_{2}\right)$ & 3.437 & 0.000 & $<$ & 0.05 & Sig & $\begin{array}{l}\mathrm{H}_{0} \text { ditolak } \\
\mathrm{H}_{2} \text { diterima }\end{array}$ \\
\hline
\end{tabular}

Berdasarkan tabel 10 di atas, menunjukkan bahwa: (1) Variabel Rekrutmen secara parsial berpengaruh signifikan terhadap kinerja karyawan pada Hotel Oase Pekanbaru; dan (2) Variabel penempatan kerja secara parsial berpengaruh signifikan terhadap kinerja karyawan pada Hotel Oase Pekanbaru.

Pengujian ini dilakukan untuk mengetahui apakah variabel independen secara bersama-sama menjelaskan variabel dependen. Analisa uji $\mathrm{F}$ dilakukan dengan membandingkan $\mathrm{F}$ hitung dan $F$ tabel. Namun sebelum membandingkan nilai $\mathrm{F}$ tersebut, harus ditentukan tingkat kepercayaan (1- $\alpha$ ) dan derajat kebebasan (degree of freedom) $=\mathrm{n}$ - $(\mathrm{k}+1)$ agar dapat ditentukan nilai kritisnya. Adapun nilai Alpha yang digunakan dalam penelitian ini adalah sebesar 0,05. Adapun hasil uji F dapat dilihat pada tabel berikut ini:

Tabel 11

Rekapitulasi Hasil Pengujian Hipotesis Secara Simultan (Uji F)

\begin{tabular}{ccccccc}
$\mathbf{F}_{\text {hitung }}$ & Sig & Tanda & Alpha $(\boldsymbol{\alpha})$ & Ket & \multicolumn{2}{c}{ Hipotesis } \\
\hline 20.361 & 0.0 & $<$ & 0.05 & Sig & $\mathrm{H}_{\mathrm{a}}$ diterima & $\mathrm{H}_{0}$ ditolak \\
\hline
\end{tabular}

Dari tabel 11 di atas, diketahui bahwa nilai $F_{\text {hitung }} 20.361$ atau Sig 0,000 $<0.05$ yang berarti $\mathrm{H}_{\mathrm{a}}$ diterima dan $\mathrm{H}_{0}$ ditolak. Hal ini menunjukkan bahwa variabel rekrutmen dan penempatan kerja secara bersama-sama berpengaruh signifikan terhadap kinerja karyawan pada Hotel Oase Pekanbaru.
Koefisien Determinasi $\left(\mathrm{R}^{2}\right)$ adalah sebuah koefisien yang digunakan untuk melihat seberapa besar variabel independen (rekrutmen dan penem-patan kerja) dapat menjelaskan variabel dependennya (kinerja). 
Tabel 12

Rekapitulasi Hasil Pengujian Koefisien Determinasi $\left(\mathbf{R}^{2}\right)$

\begin{tabular}{|c|c|c|c|c|c|}
\hline Model & $\mathrm{R}$ & $\begin{array}{c}\mathrm{R} \\
\text { Square }\end{array}$ & Adjusted R Square & $\begin{array}{l}\text { Std. Error of the } \\
\text { Estimate }\end{array}$ & Durbin-Watson \\
\hline 1 & $.767^{\mathrm{a}}$ & .652 & .703 & 3.16811 & 1.554 \\
\hline
\end{tabular}

a. Predictors: (Constant), Penempatan, Rekrutmen

b. Dependent Variable: Kinerja

Berdasarkan tabel 12 di atas,

Oase Pekanbaru. Sedangkan sisanya diketahui bahwa nilai Korelasi (R) yang dihasilkan adalah sebesar 0.767. Dengan demikian, maka dapat disimpulkan bahwa terdapat hubungan yang erat antara variabel rekrutmen dan penempatan kerja. Hal ini dikarenakan nilai korelasi sebesar 0.767 mendekati angka 1.

Sedangkan nilai Adjusted R Square sebesar 0.703. Hal ini menunjukkan bahwa variabel rekrutmen dan penempatan kerja secara keseluruhan memberikan pengaruh sebesar $70.3 \%$ terhadap kinerja karyawan pada Hotel Oase Pekanbaru. Sedangkan sisanya sebesar 29,7 \% adalah dipengaruhi oleh variabel lain yang tidak di teliti dalam penelitian ini.

\section{SIMPULAN}

Berdasarkan hasil penelitian di atas, maka dapat diambil beberapa kesimpulan yakni Faktor-faktor yang mempengaruhi kinerja karyawan pada Hotel Oase Pekanbaru adalah dipengaruhi oleh rekrutmen dan penempatan kerja.

Berdasarkan hasil perhitungan Uji F, diketahui bahwa nilai $\mathrm{F}$ hitung 20.361 atau Sig $0,000<0.05$ yang berarti $\mathrm{H}_{\mathrm{a}}$ diterima dan $\mathrm{H}_{0}$ ditolak. Hal ini menunjukkan bahwa variabel rekrutmen dan penempatan kerja secara bersama-sama berpengaruh signifikan terhadap kinerja karyawan pada Hotel Oase Pekanbaru.

Berdasarkan hasil perhitungan Koefisien Determinasi diperoleh nilai Adjusted R Square sebesar 0.703. Hal ini menunjukkan bahwa variabel rekrutmen dan penempatan kerja secara keseluruhan memberikan pengaruh sebesar $70.3 \%$ terhadap kinerja karyawan pada Hotel sebesar 29,7 \% adalah dipengaruhi oleh variabel lain yang tidak di teliti dalam penelitian ini.

\section{DAFTAR KEPUSTAKAAN}

Alex, Nitisemito S., 2002. Manajemen Personalia. Jakarta: Halia Indonesia.

Astuti, D., \& Maharani, D. 2015. Kompetensi Lulusan Sarjana Ekonomi Syariah Dalam Dunia Kerja (Urgensi dan Harapan). Al-Hikmah: Jurnal Agama dan Ilmu Pengetahuan, 12(2), 132-151.

Arikunto, Suharsimi. 2006. Prosedur Penelitian Suatu Pendekatan Praktik edisi revisi VI, Jakarta : PT. Rineka Cipta.

Ghozali, Imam. 2005. Analisis Multivariate dengan Program SPSS. Semarang: Badan Penerbit Universitas Diponegoro.

Hadari, Nawawi. 2000. Manajemen Sumber Daya Manusia, Cetakan ke tiga. Yogyakarta: Gajah Mada Universiti Press.

Hani, Handoko T., 2003. Manajemen Personalia dan Sumber Daya Manusia, Cet-9. Yogyakarta: BPEE.

Hariandja, Marihot Tua Efendi. 2002. Manajemen Sumber Daya Manusia: Pengadaan, Pengembangan, Pengkompensasian, dan Peningkatan Produktivitas Pegawai. Jakarta: Gramedia Widiasarana Indonesia.

Hasibuan, S.P, Melayu. 2001. Manajemen Sumber Daya Manusia. Jakarta: Bumi Aksara.

Irawan, Prasetya. 2004. Logika dan Prosedur Penelitian. STIA LAN Press. 
Martoyo, Susilo. 2000. Manajemen Sumber Daya Manusia, Edisi ke empat, cetakan pertama. Yogyakarta: BPFE.

Mathis, I Robert. 2001. Manajemen Sumber Daya Manusia. Jakarta: Salemba Empat.

Mangkunegara, A.A. Anawar, Prabu. 2000. Manajemen Sumber Daya Perusahaan.

Bandung: PT. Rosda Karya.

Moekijat. 2003. Manajemen Tenga Kerja dan Hubungan Kerja. Bandung: CV. Pionir Jaya.

Musliadi. 2010. Pengaruh Pelatihan dan Pengembangan serta Penempatan Terhadap Prestasi Kerja Karyawan pada PT. PN V Pekanbaru. Pekanbaru: FEKONSOS UIN SUSKA Riau.

Rivai, Vithzal. 2006. Manajemen Sumber Daya Manusia untuk Perusahaan, Cet. 1. Jakarta: PT. Raja Grafindo Persada. Rusby, Z., Bakhri, B. S., \& Rozi, S. 2017. Pengaruh Bauran Promosi Terhadap Peningkatan Jumlah Tamu pada Wisma Graha Az-Zahra Pekanbaru. AL-HIKMAH, 14(2), 222241.

Sastrohadiwiryo, B. Siswanto. 2001. Manajemen Tenaga Kerja Indonesia : Pendekatan Administrasi dan Operasional. Jakarta: Bumi Aksara.

Simamora, Henry. 2004. Manajemen Sumber Daya Manusia. Yogyakarta: STIE YPKN.

Sugiono. 2006. Metode Penelitian Administrasi. Bandung: ALFA BETA.

Thohardi, Ahmad. 2002. Manajemen Sumber Daya Manusia. Jakarta: Mandar Maju.

Umar, Husein. 2001. Riset Sumber Daya Manusia dalam Organisasi. Jakarta: PT. Gramedia Pustaka Utama.

UU Ketenagakerjaan No. 25 Tahun 1999. Jakarta: Departemen Tenaga Kerja dan Transmigrasi.
Wati, Nurcahaya. 2009. Analisis Rekrutmen Karyawan pada PT. Riau Media Televisi (RTV). Pekanbaru: FEKONSOS UIN SUSKA Riau. 